\title{
Exposure of rural households to toxic cyanobacteria in container-stored water
}

\author{
E Fosso-Kankeu ${ }^{1}, \mathrm{P}$ Jagals ${ }^{1 *}$ and $\mathrm{H}$ du Preez ${ }^{2}$ \\ ${ }^{1}$ Water and Health Research Unit, Faculty of Health Sciences, University of Johannesburg, PO Box 17011, Doornfontein 2028, \\ Johannesburg, South Africa \\ ${ }^{2}$ Analytical Services, Hydrobiology Section, Barrage Road, PO Box 3526, Vereeniging, South Africa and Department of Zoology, \\ Faculty of Science, University of Johannesburg, PO Box 524, Auckland Park 2006, Johannesburg, South Africa
}

\begin{abstract}
Cyanobacteria are potent producers of cyanotoxins that may present a health risk to people. This is especially important in rural areas where people use untreated surface water, containing cyanobacteria, for household purposes including cooking and drinking. Water is collected from these sources mainly in plastic containers, transported home and stored during use. This study investigated the occurrence of cyanobacteria and their associated toxins in these containers as well as in the associated surface water sources. The results suggest that cyanobacteria are transferred from the water sources to the containers and then survive and possibly grow in biofilm forming inside the vessels. Their associated cyanotoxins were not found in any health-significant quantities in containers. However, the occurrence of cyanobacteria in the water used by the households collected in containers clearly indicates that it can be an important route of exposure especially if toxic cyanobacteria are present in the source water. In several cases a risk of cyano-intoxication might exist unless the households undertake preventative measures.
\end{abstract}

Keywords: cyanobacteria, cyanotoxin, microcystin, surface water sources, drinking water containers, biofilm

\section{Introduction}

Cyanobacteria occur in surface waters, especially in waters where physical conditions and nutrient loads are favourable for their proliferation (Whitton and Potts, 2000). Several of the cyanobacteria genera produce cyanotoxin and subsequently may pose a human health risk, especially after direct contact with, or ingestion of water contaminated with these genera (Chorus and Bartram, 1999; Codd et al., 1997). Seven toxic cyanobacteria genera (targeted in this study) are most likely to be encountered in surface water sources. These are Microcystis spp., Oscillatoria spp., Anabaena spp., Cylindrospermopsis spp., Aphanizomenon spp., Nodularia spp. and Nostoc spp. (Chorus and Bartram, 1999), of which Microcystis spp. are reported to be the most abundant. These cyanobacteria are potential producers of cyanotoxins of which the most common type is the microcystins (Du Preez et al. 2007; Du Preez and Van Baalen 2006; Chorus and Bartram, 1999; Carmichael, 1992).

People in underdeveloped areas are reportedly using untreated surface water directly from the source for washing, preparing food and drinking. These water sources are often contaminated by substantial numbers of pathogenic bacteria (Jagals, 2006; Jagals et al., 2003), including toxic cyanobacteria (WHO, 2004; Chorus and Bartram, 1999). In the Southern African context, water for household uses in rural villages is being collected from the water source mostly in 20 to $25 \ell$ plastic containers and stored at home to be used over several days. The quality of the water source as well as the manner in which the water from the

* To whom all correspondence should be addressed. Present address: Tshwane University of Technology, Private Bag X680, Pretoria 0001, South Africa

푱 +2712 3823543; fax: +27123825262 ;

e-mail: agalsp@.tut.ac.za storage containers is being used by the household, poses a health risk to the users. The risk of infection is high as pathogenic bacteria may be collected with the source water or may develop in the container. Seeded and/or neophyte bacteria could proliferate in container waters and eventually attach to containers' inner sidewalls, forming biofilm, further sustaining their occurrence and proliferation (Jagals et al., 2003; Momba and Kaleni, 2002). It is postulated that cyanobacteria and / or their cyanotoxins can also be collected with the source water into containers but it is not known what typical cyanobacteria numbers and their associated toxin levels are collected with the containers or whether the cyanobacteria would proliferate and produce toxin in the container water.

The aim of this work was therefore to assess whether cyanobacteria and microcystins occur at levels in the water from the containers that pose a health problem to the household using it.

\section{Methodology}

Water was sampled from containers in households from rural villages in the semi-tropical Vhembe district of the Limpopo Province in South Africa (Fig. 1). These villages are not supplied with potable water via conventional piped drinking water supply systems. The population uses untreated water from surface sources such as nearby rivers and streams. This study was conducted during the 7 months of high summer in the area to assess cyanobacteria occurrences under conditions conducive to optimum growth, i.e. the assessments were done of the worstcase scenario in terms of consumer exposure to cyanobacteria and their cyanotoxins.

\section{Sampling}

All the households in the area typically used 20 to $25 \ell$ plastic containers to collect and store water. The container material 


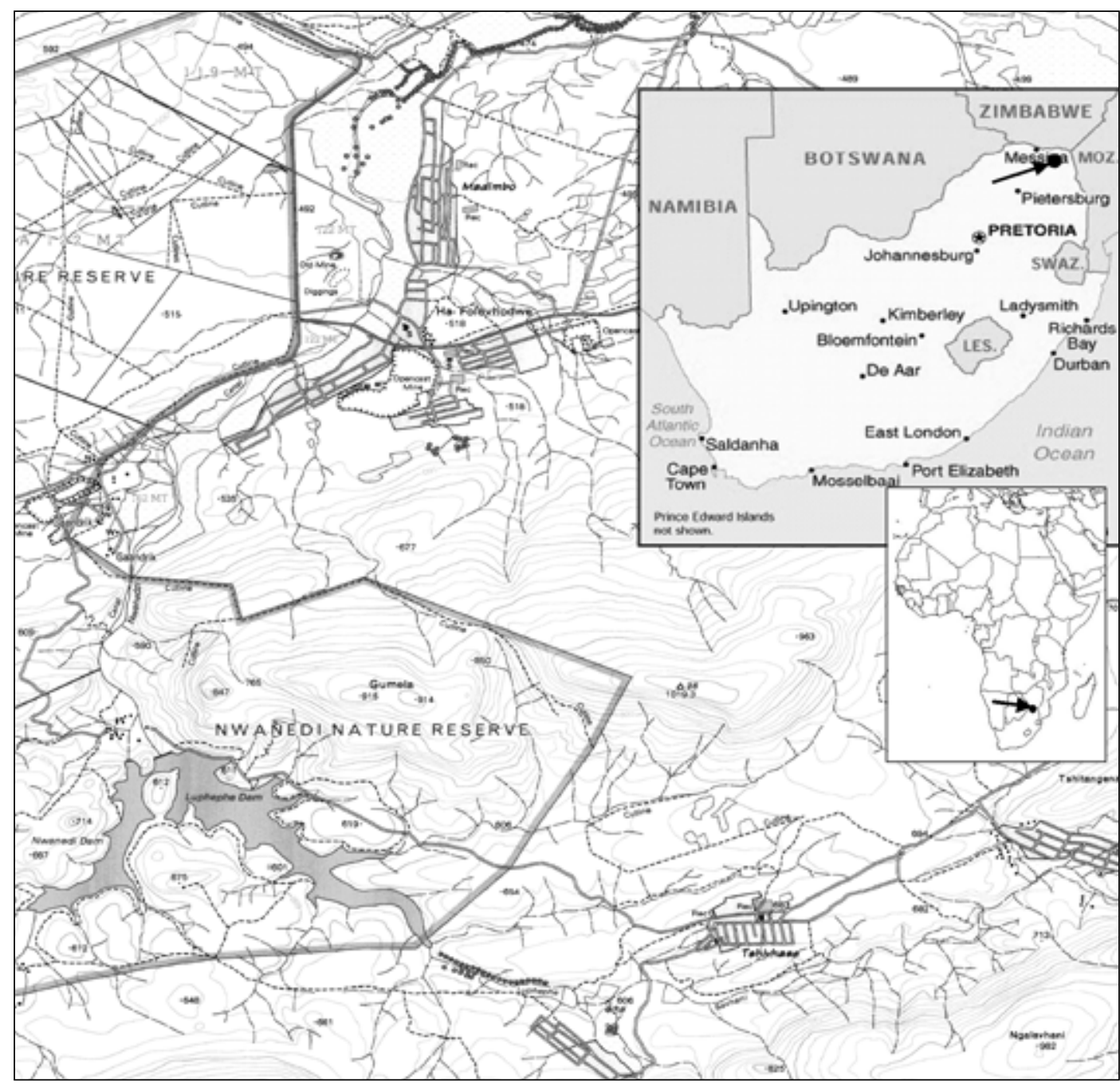

Figure 1

Study area situated at the north-eastern corner of the Limpopo Province

varied in colour, variations mostly being of light-coloured (light-permissible) and dark-coloured (light-limiting) plastic. Since light plays an important role in the proliferation of cyanobacteria, this offered a robust method to investigate the role that the light-permissibility of the vessels' material could play in the occurrence of toxic cyanobacteria and their associated cyanotoxin in the containers. An important inclusion criterion was therefore that a participating household would use both a light-coloured (L) and a dark-coloured (D) container for the collection and storage of water for household purposes.

\section{Container-water sampling}

Twenty households were randomly selected from 203 households that sourced water directly from two shallow nearby rivers. Sampling visits were paid to each household every 6 to 8 weeks during the 7 months of high summer, with the sampling done within $4 \mathrm{~h}$ after the households had collected water from the rivers and 4 samples were taken from a household during each visit. In total, 236 samples were taken during 59 visits. Firstly Samples 1 and 3 were collected from the free volume of water in each container type ( $\mathrm{L}$ and $\mathrm{D}$ ), referred to as the FV sample type. This was to attribute cyanobacteria contamination of the FV to the source water. Directly after, biofilm on the sidewalls of the same containers was dislodged by brushing the sidewalls with a sterilised long-handle brush (Jagals et al.,
2003). The dislodged biofilm particles were suspended in the free volume of container water by swirling the container and follow-up Samples 2 and 4 were taken (the DB sample). This was to associate potential increases in cyanobacteria numbers in the container water to the presence of biofilm that had formed in the containers.

Each sample $(100 \mathrm{~m} \ell)$ was collected in an amber bottle and preserved by adding $2 \mathrm{~m} \ell$ of acidified formaldehyde solution (Swanepoel et al., 2007). In the laboratory the DB samples were subjected to vigorous shaking to further emulsify the biofilm particles and to release whatever organisms there might be in the particles.

For microcystin assessment, 10 samples were collected from the LDB-containers in sterile brown glass bottles and transported to the laboratory at $<10^{\circ} \mathrm{C}$. These samples were taken from LDB-containers because waters from these containers were expected to yield the higher numbers of cyanobacteria and therefore were the most likely to contain measurable quantities of microcystin.

\section{Source-water sampling}

Eight samples were collected throughout the summer from the two surface water sources at points where the households collected water. These samples were collected to perform cyanobacteria identification and enumeration as well as selected physical and chemical analyses. 
The cyanobacteria identification and enumeration were done by following the sedimentation technique whereby a sedimentation chamber containing 3 to $5 \mathrm{~m} \ell$ of sample was centrifuged to allow the cyanobacteria cells to settle on the bottom and then analysed under an inverted light microscope (Swanepoel et al., 2007). Analyses for microcystin were performed with competitive enzyme-linked immunosorbent assays (ELISA) using Envirologix Quantiplate Microcystin kits from Adcock Ingram SA, as described by Swanepoel et al. (2007).

Factors considered important in the growth and sustenance of cyanobacteria were also measured in the same water samples. Physical light was not measured since it was assumed that the light permissibility of the two container material types would reflect the role that light would play in cyanobacteria occurrence and proliferation in containers. At each site the temperature and $\mathrm{pH}$ were measured with a portable Hanna ${ }^{\circledR}$ instrument (HI $991301 \mathrm{pH} / \mathrm{EC} / \mathrm{TDS} / \mathrm{Temp}$ ). As an indicator of the amounts of biofilm dislodged from the container inner sidewalls, the turbidity of the samples was measured afterwards in the laboratory with a Nephla turbidity meter (Dr Lange GmbH-Berlin). To reflect the nutrient concentration in the sampled waters, total nitrate and phosphate were measured with a Xion 500 spectrophotometer (Dr Lange GmbH-Berlin).

\section{Health-related parameters}

To postulate on the implications for health, the cyanobacteria and microcystin levels were assessed for compliance (at the $95^{\text {th }}$ percentile) according to the WHO-derived values shown in Table 1.

\begin{tabular}{|l|c|c|}
\hline \multirow{3}{*}{$\begin{array}{c}\text { TABLE 1 } \\
\text { Guidelines for permissible levels of cyanobacteria } \\
\text { and microcystin in water intended for drinking }\end{array}$} \\
\hline Parameters & World Health Organisation guidelines \\
\cline { 2 - 3 } & Unit & Guideline \\
\hline Cyanobacteria & $\mathrm{Cell} / \mathrm{m} \ell$ & $2000(\mathrm{WHO}, 1999)$ \\
\hline Microcystin LR & $\mu \mathrm{g} / \ell$ & $1(\mathrm{WHO}, 2004)$ \\
\hline
\end{tabular}

\section{Statistical analysis}

All the data were recorded in Microsoft ${ }^{\circledR}$ Excel. ANOVA was used to derive geometric mean values as well as guideline compliance at the $95^{\text {th }}$ percentile. The numbers of cyanobacteria in the free volume of water were compared to the numbers occurring in the water samples containing dislodged biofilm as well as between the two types of containers. Free volume and dislodged biofilm data from the same container type were considered as parametric, and non-parametric if belonging to different container types. The difference between parameters was measured by sign rank, rank sum and Kruskal-Wallis tests, and deemed significant if the level of probability was $\leq 0.05$.

\section{Results and discussion}

\section{Part 1:Cyanobacteria and microcystin in containers}

\section{Cyanobacteria}

Cyanobacteria did not occur consistently in container water samples, with overall $40 \%$ (94) of the samples testing positive for cyanobacteria (LFV: $43 \%$ positive; $\mathrm{LDB}$ : $57 \%$ positive; $\mathrm{DFV}$ : $34 \%$ positive; DDB: $26 \%$ positive). However, for statistical analyses of the data, a complete sample set (LFV, LDB, DFV and DDB per household per visit) was considered to be positive, even if only 1 of the 4 samples was positive. This constituted 38 of the 59 sample sets.

Three cyanobacteria genera namely Microcytis, Oscillatoria, and Anabaena were detected in the positive samples (Fig. 2).

Microcystis spp. were the dominant genus to the extent that it constituted between 70 and $80 \%$ of the total toxic cyanobacteria in the waters sampled from the containers (Table 2 - next page).

The numbers of cyanobacteria in LDB samples were significantly higher $(\mathrm{P}=0.004)$ than in the LFV, DFV and DDB groups. The respective numbers for these three sample groups did not differ significantly $(P=0.349)$. This implied that, while cyanobacteria did occur in the free volumes of water of all 'positive' containers (probably being harvested from the untreated surface water source), the higher numbers of cyanobacteria in the DB samples from the light-permissible containers were probably built up and sustained in the container biofilm, a tendency reported by Jagals et al (2003) for other health-related indicator organisms such as total coliforms.

The increased levels of cyanobacteria sampled from containers in the free volume of water, could also be the consequence of the biofilm releasing bacteria from the sidewalls during the filling and handling of the containers as reported by Jagals et al. (2003) as well as by Momba and Kaleni (2002).

Although relatively low, the concentrations of nitrate and phosphate (major nutrients for cyanobacteria) in containers waters should have been sufficient to sustain the growth of cyanobacteria in terms of minimum values $(10 \mu \mathrm{g} / \ell$ and 100 $\mu \mathrm{g} / \ell$ respectively) proposed by the WHO (1999) and Rusin et al. (2000). The physical conditions ( $\mathrm{pH}$ and temperature) were

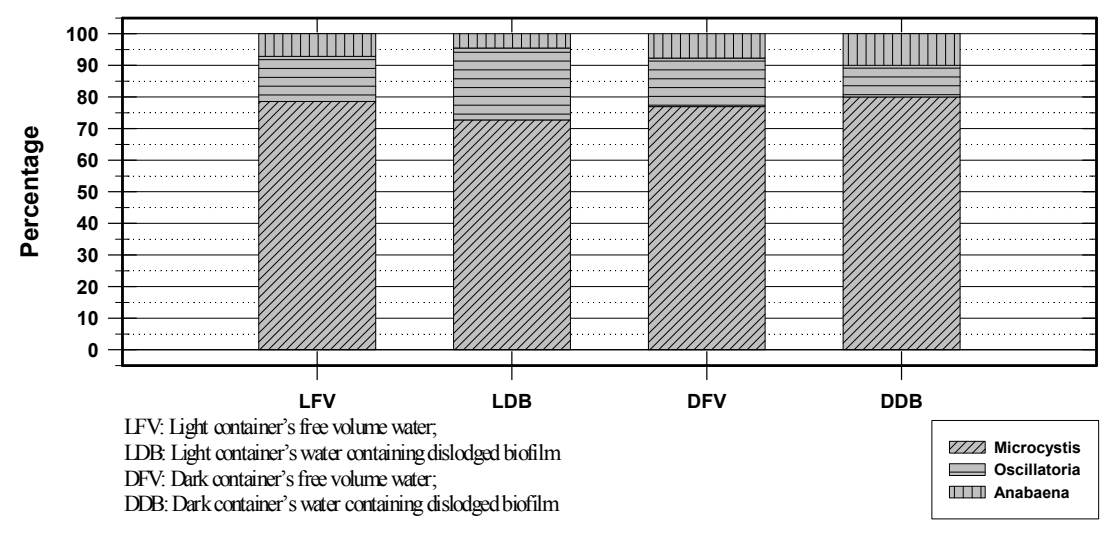

Figure 2

Percentage of cyanobacteria genera in positive samples of water from storage containers 


\begin{tabular}{|c|c|c|c|c|c|}
\hline \multicolumn{6}{|c|}{$\begin{array}{c}\text { TABLE } 2 \\
\text { Levels of cyanobacteria, turbidity and nutrier }\end{array}$} \\
\hline $\begin{array}{l}\text { Positive } \\
\text { sample sets } \\
(n=38)\end{array}$ & $\begin{array}{c}\text { Data } \\
\text { descriptors }\end{array}$ & $\begin{array}{c}\text { Total } \\
\text { cyanobacteria } \\
(\log \text { cell } / \mathrm{m} \ell)\end{array}$ & $\begin{array}{l}\text { Turbidity } \\
\text { (NTU) }\end{array}$ & $\begin{array}{l}\text { Nitrate } \\
(\mathrm{mg} / \mathrm{l})\end{array}$ & $\begin{array}{l}\text { Phosphate } \\
\text { (mg/l) }\end{array}$ \\
\hline \multirow[t]{4}{*}{ LFV } & Mean & 0.89 & 30 & 2.3 & 0.1 \\
\hline & Range & nd -4.4 & $0.5-210$ & $0.3-51$ & $0.02-2.7$ \\
\hline & $95^{\text {th }}$ Perc & 4.2 & 198.2 & 7.5 & 0.4 \\
\hline & $95 \% \mathrm{Ci}$ & 0.8 & 25.1 & 2.7 & 0.2 \\
\hline \multirow[t]{4}{*}{ LDB } & Mean & 2.1 & 243 & 4.3 & 0.5 \\
\hline & Range & $\mathrm{nd}-5.8$ & $1.3-666$ & $0.8-52$ & $0.03-4.7$ \\
\hline & $95^{\text {th }}$ Perc & 5.7 & 558.6 & 10.57 & 1.9 \\
\hline & $95 \% \mathrm{Ci}$ & 0.9 & 84.10 & 3.22 & 0.3 \\
\hline \multirow[t]{4}{*}{ DFV } & Mean & 0.5 & 31 & 3.1 & 0.2 \\
\hline & Range & nd -4.8 & $0.5-314$ & $0.3-56$ & $0.03-1.8$ \\
\hline & $95^{\text {th }}$ Perc & 3.7 & 173 & 7.7 & 0.9 \\
\hline & $95 \% \mathrm{Ci}$ & 0.7 & 30 & 3.5 & 0.1 \\
\hline \multirow[t]{4}{*}{ DDB } & Mean & 0.3 & 192 & 4.3 & 0.4 \\
\hline & Range & $\mathrm{nd}-5.6$ & $2.5-675$ & $1.1-55$ & $0.1-2.5$ \\
\hline & $95^{\text {th }}$ Perc & 5.1 & 629 & 8.8 & 1.3 \\
\hline & $95 \% \mathrm{Ci}$ & 0.7 & 87.7 & 3.4 & 0.2 \\
\hline \multicolumn{6}{|c|}{$\begin{array}{l}\frac{L F V}{\text { permissible container; } ;} \underline{D F V}=\text { free volume of water from a dark container; } ; \underline{L B}=\text { water with dislodged biofilm } \\
\text { from a dark container; } n=\text { number of samples; } 95 \% \mathrm{Ci}=\text { confidence interval; } 95^{\text {th }} \text { Perc }=95^{\text {th }} \text { percentile; } n d=\text { not } \\
\text { detected }\end{array}$} \\
\hline
\end{tabular}

optimum in containers waters, ranging between 6 and 9 and 20 and $35^{\circ} \mathrm{C}$ respectively. The turbidity and nutrient levels in the DB samples were significantly higher $(\mathrm{P}<0.001)$ than in FV samples.

This was regardless of the type of container since no significant difference $(\mathrm{P}>0.05)$ could be measured between these variables in light and dark container water sample types. These results show that nutrients could not have accounted for the variation in cyanobacteria numbers in the container types. The conclusion is therefore that light was the limiting factor for cyanobacteria activity in the dark containers.

The results show further that, at the $95^{\text {th }}$ percentile, the numbers of cyanobacteria in LDB and DDB samples exceeded critical levels contained in a number guidelines. Firstly, it exceeded the WHO (1999) Health Primary Alert guideline value of 2000 cells $/ \mathrm{m} \ell$ (Table 1). This value is also contained in the proposed Alert 1 contained in the Australian National Alert Levels Framework for Drinking Water (Burch et al., 2003) and the Cyanobacteria Incident Management Framework for Drinking Water Utilities, developed by Du Preez and Van Baalen (2006) and Du Preez et al. (2007)

\section{Microcystin in containers}

One of the 10 selected container samples contained microcystin but at a concentration $(0.36 \mu \mathrm{g} / \ell)$ that did not exceed the guideline value of $1 \mu \mathrm{g} / \ell$ proposed in Table 1 .

Despite high numbers of toxic cyanobacteria occurring in container water, this was not concurrent with microcystin in the same containers. Microcystin was detected in Sample 5, which contained lower numbers of cyanobacteria (310 cells/ $\mathrm{m} \ell)$ than for instance Sample 3 with the highest number $(692$ 299 cell $/ \mathrm{m} \ell$ ) of cyanobacteria. It is possible that microcystin did occur in some or all of the other nine samples - but in concentrations below the detection limit of the technique (range of detection: $0.18 \mu \mathrm{g} / \ell$ to $2.5 \mu \mathrm{g} / \ell$ ). Other reasons for the low toxin occurrence could be that the physical and chemical conditions (Van der Westhuizen et al., 1986; Van der Westhuizen and Eloff, 1985), such as those encountered in the containers would not have been conducive to the production of microcystin at the time of sampling. It is reported that environmental factors affect the variation of the toxicity of cyanobacteria (Chorus and Bartram, 1999). Work by Sivonen (1990) as well as Rapala and Sivonen (1998), showed the loss of toxigenicity by genera of Microcystis and Anabaena under variable light and nutrient conditions. It is therefore possible that although the conditions in containers were favourable for the growth and proliferation of cyanobacteria, the same conditions were not conducive to the production of microcystin by these cells.

\section{Part 2: Occurrence of cyanobacteria and microcystin} in source waters

Four genera belonging to the 7 toxic cyanobacteria genera mentioned earlier constituted the total cyanobacteria detected in samples taken from the water sources. These were again Microcystis, Anabaena, Oscillatoria and Pseudo-anabaena. Microcystis and Anabaena were the dominant genera but their occurrence varied widely, with Microcystis occurring in between 25\% and $80 \%$ of the samples. No cyanobacteria were detected in two of the samples while the numbers of cyanobacteria in two more samples did not comply, at the $95^{\text {th }}$ percentile, with the guidelines proposed in Table 1. The water sources did contain the major nutrients required for cyanobacteria growth (phosphate and nitrate) in quantities sufficient for growth.

Although not correlated specifically to households, the results in Table 3 show that source-based cyanobacteria can be the origin of those found in containers but do not necessarily contribute to the higher numbers detected in especially lightpermitting containers. This strengthens the case for containerbiofilm to be a major reservoir of cyanobacteria as it is for other water-related pathogenic bacteria. 


\begin{tabular}{|c|c|c|c|c|c|c|}
\hline \multicolumn{7}{|c|}{$\begin{array}{r}\text { TABLE } 3 \\
\text { Descriptive levels of cyanobacteria, turbidit }\end{array}$} \\
\hline & $\begin{array}{c}\text { Data } \\
\text { descriptors }\end{array}$ & $\begin{array}{c}\text { Total } \\
\text { cyanobacteria } \\
(\log \text { cell } / \mathrm{m} \ell)\end{array}$ & $\begin{array}{l}\text { Microcystin } \\
(\mu \mathrm{g} / \ell)\end{array}$ & $\begin{array}{l}\text { Turbidity } \\
\text { (NTU) }\end{array}$ & $\begin{array}{l}\text { Nitrate } \\
(\mathrm{mg} / \mathrm{l})\end{array}$ & $\begin{array}{l}\text { Phosphate } \\
\text { (mg/l) }\end{array}$ \\
\hline \multirow{4}{*}{$\begin{array}{l}\text { Source } \\
(\mathrm{n}=8)\end{array}$} & Mean & 2.15 & 0.66 & 9.03 & 0.41 & 0.05 \\
\hline & Range & nd -4.24 & $\mathrm{nd}-2.5$ & $1.4-25.7$ & $0.1-0.63$ & $0.05-0.05$ \\
\hline & $95^{\text {th }}$ Perc & 4.28 & 0.00 & 25.7 & 0.63 & 0.05 \\
\hline & $95 \% \mathrm{Ci}$ & 1.36 & 1 & 8.68 & 0.18 & 0.00 \\
\hline
\end{tabular}

Microcystin was detected in 3 of the 8 samples. In two of these, the concentrations were above the guideline value of $1 \mu \mathrm{g} / \ell$ for drinking water (Table 1$)$. This implies that microcystin could also be imported into containers.

\section{Subsequent growth of sourced cyanobacteria in containers}

This study showed that cyanobacteria also occurred in the drinking water containers. While the higher numbers of container occurrences are attributed to the presence of biofilm in these containers, the numbers in the dislodged-biofilm samples from the dark containers and the samples from the free volumes of water in both the container types were not significantly higher than those of the sources $(P \geq 0.346)$. It was only the LDB samples that were significantly higher than the numbers of cyanobacteria in the source water, DDB and both FV samples. While this indicated that the source waters were probably the source of the container cyanobacteria, the favourable conditions in the light-permitting containers contribute to the proliferation of seeded cyanobacteria.

\section{General discussion and conclusion}

On a larger scale, De Philippis et al. (2005) found that cyanobacteria could form biofilm on solid surfaces that interfaced with environmental water. Exo-polysaccharides, present on the cyanobacteria cell walls, promoted the attachment of the cell to solid surfaces and the formation of biofilm (De Philippis and Vincenzini, 1998; Sutherland, 2001). Moreover, in contrast to heterotrophic bacteria that die off during water-storage mostly because of nutrient depletion (Egwari and Aboaba, 2002; Piriou et al., 1997), cyanobacteria have the ability to synthesise their own organic nutrients using only carbon dioxide, minerals and light (Chorus and Bartram, 1999), and can therefore live under such conditions.

Results from this study showed that cyanobacteria in the household containers could be collected from the source water during water collection. Although the composition of the biofilm was not investigated, the results do suggest that cyanobacteria could increase in numbers in containers, be it through growth or sustained accumulation by growth factors in the container biofilm, especially light-permitting containers.

Microcystis spp. appeared to be the dominant genus of cyanobacteria recorded in this study. While this is in accordance with previous reports on work on environmental waters in South Africa by Du Preez and Van Baalen (2006) as well as Van Ginkel (2004), this study suggested that Microcystis might also have the ability to grow in the container, thus constituting a potentially consistent risk to the health of consumers.

Despite the apparent absence of microcystin in container waters, the health risk should not be considered negligible. The occurrence of cyanobacteria in the container water used by households clearly indicates that it can be an important route of exposure especially if there is a toxic cyanobacteria bloom in the source water. The importance of the contribution of biofilm in the containers is further highlighted. The numbers of cyanobacteria in the biofilm from especially the light-coloured containers were high enough to suggest that their ability to produce cyanotoxins constituted a consistent potential for spontaneous increases in toxin levels should conditions become favourable (Rapala and Sivonen, 1998). Furthermore lipopolysaccharide endotoxins produced by all cyanobacteria could constitute a hazard for immuno-impaired consumers although not an immediate threat for healthy people (Stewart et al., 2006).

From the analysis of the limited sources of water available in the study areas, it appears that they are of unacceptable quality for consumption. The use of dark containers will certainly limit the proliferation of cyanobacteria in stored water; however, in the case of scum occurrence at the source, it is not advisable for the population to make contact with water. Hence the need for major intervention, such as low-cost pretreatment of water (use of activated charcoal), education of the user about the need for regular observation of the physical appearance of the water, as well as action to be taken during scum occurrence, and promotion by health authorities of container hygiene to be achieved through regular brushing and sanitising of containers to keep the vessel free of biofilm.

\section{Acknowledgements}

The National Research Foundation, Analytical Services of Rand Water in particular Annelie Swanepoel and Leonie van Baalen, as well as our colleagues at the Water and Health Research Unit, University of Johannesburg.

\section{References}

BURCH MD, HARVEY FL, BAKER PD and JONES G (2003) National Protocol for the Monitoring of Cyanobacteria and their Toxins in Surface Fresh Waters. ARMCANZ - National Algal Management Draft V60 for consideration LWBC.

CARMICHAEL WW (1992) Cyanobacteria secondary metabolitescyanotoxins. J. Appl. Bacteriol. 72 445-459.

CHORUS I and BARTRAM J (eds.) (1999) Toxic Cyanobacteria in Water. A Guide to their Public Health Consequences, Monitoring and Management. Published on behalf of the World Health Organisation by E \& FN Spon, London. 416 pp.

CODD GA, WARD CJ and BELL SG (1997) Cyanobacterial toxins occurrence, modes of action, health effects and exposure routes. In: Seiler JP and Vilanova E (eds.) Applied Toxicology: Approaches Through Basic Science. Arch. Toxicol. Suppl. 19. Springer, Berlin. 399-410.

DE PHILIPPIS R and VINCENZINI M (1998) Exocellular polysaccharides from cyanobacteria and their possible applications. FEMS Microbiol. Rev. 22 75-151. 
DE PHILIPPIS R, FARALONI C, SILI C and VINCENZINI M (2005) Population of exopolysaccharide-producing cyanobacteria and diatoms in the mucilaginous benthic aggregates of the Tyrrhenian Sea (Tusean Archipelago). Sci. Total Environ. 353 360-368.

DU PREEZ HH and VAN BAALEN (2006) Generic Incident Management Framework for Toxic Blue-Green Algal Blooms, for Application by Potable Water Supplies. WRC Report No TT 263/06. Water Research Commission, Pretoria, South Africa. 65 pp.

DU PREEZ HH, SWANEPOEL A, VAN BAALEN L and OLDEWAGE A (2007) Cyanobacterial Incident Management Frameworks (CIMFs) for application by drinking water suppliers. Water SA 33 643-652. http://www.wrc.org.za/downloads/watersa/2007/Oct $\% 20$ 07/2121.pdf

EGWARI L and ABOABA OO (2002) Environmental impact on the bacteriological quality of domestic water supplies in Lagos, Nigeria. Revista de Saude Publica 36 (4) 513-520.

JAGALS P (2006) Does improved access to water supply by rural households enhance the concept of safe water at the point of use? A case study from deep rural South Africa. Water Sci. Technol. 54 (3) $9-16$.

JAGALS P, JAGALS C and BOKAKO TC (2003) The effect of container-biofilm on the microbiological quality of water used from plastic household containers. J. Water Health 1 (3) 101-108.

MOMBA MNB and KALENI P (2002) Regrowth and survival of indicator microorganisms on the surfaces of household containers used for the storage of drinking water in rural communities of South Africa. Water Res. 36 3023-3028.

PIRIOU PH, DUKAN S, LEVI Y and JARRIGE PA (1997) Prevention of bacterial growth in drinking water distribution systems. Water Sci. Technol. 35 (11-12) 283-287.

RAPALA J and SIVONEN K (1998) Assessment of environmental conditions that favor hepatotoxic and neurotoxic Anabaena spp. Strains cultured under light limitation at different temperatures. Microbial Ecol. 36 181-192.

RUSIN P, ENRIQUEZ CE, JOHNSON D and GERBA CP (2000) Environmentally transmitted pathogens. In: Maier RM, Pepper I and
Gerba C (eds.) Environmental Microbiology. Academic Press, San Diego, USA.

SIVONEN K (1990) Effects of light, temperature, nitrate, orthophosphate, and bacteria on growth of and hepatotoxin production by Oscillatoria agardhii strains; applied and environmental microbiology. Am. Soc. Microbiol. 56 (9) 2658-2666.

STEWART I, SCHLUTER PJ and SHAW G (2006) Cyanobacterial lipopolysaccharides and human health-a review. $65 \mathrm{p}$. http://espace library.uq.edu.au/eserv/UQ:9104/cyano review2.pdf

SUTHERLAND IW (2001) Biofilm exopolysaccharides: a strong and sticky framework. Microbiol. 147 3-9.

SWANEPOEL A, DU PREEZ H, SCHOEMAN C, JANSE VAN VUUREN S and SUNDRAM A (2007) Condensed Laboratory Methods for Monitoring Phytoplankton, including Cyanobacteria, in South African Freshwaters. WRC Report No TT 323/08. Water Research Commission, Pretoria, South Africa.106 pp.

VAN DER WESTHUIZEN AJ and ELOFF JN (1985) Effects of temperature and light on toxicity and growth of the blue-green alga Microcystis aeruginosa [UV-006]. Planta. 163 55-59.

VAN DER WESTHUIZEN AJ, ELOFF JN and KRUGER GHJ (1986) Effect of temperature and light (fluence rate) on the composition of the toxin of the cyanobacterium Microcystis aeruginosa (UV-006). Arch. Hydrobiol. 108 145-154.

VAN GINKEL CE (2004) A National Survey of the Incidence of Cyanobacterial Blooms and Toxin Production in Major Impoundments. Internal Report No. N/0000/00/DEO/0503. Resource Quality Services, Department of Water Affairs and Forestry, Pretoria, South Africa.

WHITTON BA and POTTS M (2000) (eds.) The Ecology of Cyanobacteria. Kluwer Academic Publishers, Netherlands. 1-11.

WORLD HEALTH ORGANISATION (1999) Toxic Cyanobacteria in Water: A Guide to their Public Health Consequences, Monitoring and Management, Laboratory Analysis of Cyanotoxins. Geneva, Switzerland

WORLD HEALTH ORGANISATION (2004) Guidelines for Drinking Water Quality ( $3^{\text {rd }}$ edn.). WHO Library Cataloguing in Publication Data; Geneva, Switzerland. 